\title{
TEORI KEBIJAKAN KRIMINALISASI TERKAIT PERUMUSAN SANKSI PIDANA DALAM PERATURAN DESA
}

\author{
Adang Moelyono ${ }^{1}$ \\ Fakultas Hukum Universitas Islam Lamongan
}

\begin{abstract}
ABSTRAK
Penetapan sanksi dalam Peraturan Daerah, apapun jenis dan bentuk sanksi harus didasarkan pada kewenangan yang diberikan pada daerah dalam merumuskan Peraturan Daerah pidana dan diorientasikan pada standar tujuan pemidanaan. Setelah tujuan pemidanaan ditetapkan, barulah jenis dan bentuk sanksi apa yang paling tepat bagi pelanggaran Peraturan Daerah itu
\end{abstract}

\section{Kata Kunci : Teori Kebijakan Kriminalisasi, Sanksi Pidana, Peraturan Desa.}

\section{Pendahuluan}

Pada 31 Desember 2014 Kementrian

Dalam Negeri mengeluarkan Peraturan Menteri Dalam Negeri Republik Indonesia Nomor 111 tahun 2014 tentang Pedoman Teknis Peraturan di Desa. Jenis Peraturan yang diatur di Permendagri 111 tahun 2014 ini adalah tentang Peraturan Desa, Peraturan Bersama Kepala Desa, dan Peraturan Kepala Desa. Peraturan di Desa tersebut dijelaskan dalam Pasal 3 tetap dilarang bertentangan dengan kepentingan umum, dan/atau ketentuan Peraturan Perundangundangan yang lebih tinggi.

Permendagri 111 tahun 2014 ini mencabut Peraturan Menteri Dalam Negeri Nomor 29 Tahun 2006 tentang Pedoman Pembentukan dan Mekanisme Penyusunan Peraturan Desa

\section{Pasal 4}

(1) Peraturan Desa sebagaimana dimaksud dalam Pasal 2 huruf a berisi materi pelaksanaan kewenangan desa dan penjabaran lebih lanjut dari Peraturan Perundang-undangan yang lebih tinggi.

(2) Peraturan bersama Kepala Desa sebagaimana dimaksud dalam Pasal 2 huruf $b$ berisi materi kerjasama desa.

(3) Peraturan Kepala Desa sebagaimana dimaksud dalam Pasal 2 huruf c berisi materi pelaksanaan peraturan desa, peraturan bersama kepala desa dan tindak lanjut dari peraturan perundang-undangan yang lebih tinggi.

Hukum Pidana dalam perkembangannya ternyata semakin banyak digunakan dan diandalkan dalam rangka mengatur dan menertibkan masyarakat melalui peraturan perundang-undangan. Dinamika hukum dapat terlihat dari adanya kebijakan penggunaan sanksi pidana melalui pencantuman bab tentang "ketentuan sanksi pidana" pada bagian akhir sebagian besar produk peraturan perundang-

\footnotetext{
${ }^{1}$ Dosen Fakultas Hukum Universitas Islam Lamongan.
} 
undangan di Indonesia. Pencantuman bab tentang ketentuan sanksi pidana tersebut tidak hanya terlihat dalam produk peraturan perundang-undangan pusat yangberbentuk "Undang-undang", melainkan dapat terlihat pula dalam produk peraturan perundangundangan lokal yang berbentuk "Peraturan Daerah". Pembentukan Peraturan Daerah oleh Pemerintah Daerah dapat dilakukan untuk kebijakan kriminalisasi5 dalam Peraturan Daerah dan untuk penegakannya dapat membentuk pejabat-pejabat yang diberi wewenang untuk melakukan penyidikan terhadap dugaan pelanggaran atas Peraturan Daerah. ${ }^{2}$

Kebijakan kriminalisasi dalam Peraturan Daerah yang tidak sinkron di Indonesia, dapat di kelompakan menjadi empat macam, yaitu: ${ }^{3} 1$. Kebijakan kriminalisasi dari delegasi Undang-undang, contohnya Peraturan Daerah tentang Retribusi dan Pajak; 2. Kebijakan kriminalisasi yang sudah diatur dalam hukum pidana kodifikasi, contohnya Peraturan Daerah tentang miras, pelacuran;

2 Menurut Barda Nawawi Arief proses kriminalisasi harus memperhatikan berbagai aspek pertimbangan sebagai berikut: a) Penggunaan hukum pidana harus memperhatikan tujuan pembangunan nasional, yaitu mewujudkan masyarakat adil dan makmur yang merata material spiritual berdasarkan Pancasila; b) Perbuatan yang diusahakan untuk dicegah atau ditanggulangi dengan hukum pidana harus merupakan perbuatan yang tidak dikehendaki, yaitu perbuatan yang mendatangkan kerugian (material dan atau spritual) atas warga masyarakat; c) Penggunaan hukum pidana harus pula memperhitungkan prinsip biaya dan hasil (cost and benafit principles) juga sosial cost atau biaya sosial;
3. Kebijakaran kriminalisasi dari hukum Islam, contohnya Qanun Provinsi Nangroe Aceh Darussalam Nomor 11 Tahun 2002 tentang Pelaksanaan Syariat Islam Bidang Aqidah, Ibadah dan Syari'at Islam; 4. Kebijakan kriminalisasi dari hukum adat, contohnya Peraturan Daerah mengenai tradisi adat yang masih dipertahankan di daerah itu. Contohnya Peraturan Daerah Nomor 12 tahun 1999 tentang Penggalian Jalan, Mengubah Trotoar dan Pemancangan di Wilayah Kabupaten Daerah Tingkat II Badung.

Perbedaan kebijakan formulasi sanksi pidana masing-masing daerah dalam menentukan jenis atau maksimumnya sanksi pidana dalam Peraturan Daerah karena tidak ada pedoman yang pasti dan perbedaan antara satu undang-undang dengan undangundang lain, sebagai contoh pada Pasal 143 ayat (2) UU Nomor 32 Tahun 2004. Apabila dihubungkan dengan UU Nomor 18 Tahun 1997 tentang Pajak dan Retribusi Daerah, ternyata tidak adanya kesetaraan.

d) Penggunaan hukum pidana harus pula memperhatikan kapasitas atau kemampuan daya kerja dari badan-badan penegak hukum, yaitu jangan sampai ada kelampauan beban tugas (overbelasting). Lihat Barda Nawawi Arif, Bunga Rampai Kebijakan Hukum Pidana, PT. Citra Aditya Bakti, Bandung, 1996, h. 33-34

3 Teguh Prasetyo, Kebijakan Kriminalisasi Peraturan Daerah Guna Mewujudkan Sinkronisasi Hukum Pidana Lokal dengan Hukum Pidana Kodifikasi, Disertasi, Program Pascasarjana Fakultas Hukum Universitas Islam Indonesia, Yogyakarta,2006 
Jenis pidana maupun maksimum sanksi yang ditetapkan Pasal 37 sampai dengan Pasal 41 UU Nomor 18 Tahun 1997 tentang Pajak dan Retribusi Daerah yang menunjukkan bahwa maksimum sanksi pidana berkisar antara 6 bulan sampai dengan 2 tahun, sehingga ancaman pidana yang dijatuhkan dalam hal sanksi pidana pajak dan sanksi retribusi daerah dapat berupa jenis pidana kurungan atau pidana penjara. Keadaan ini tentu saja dapat menimbulkan persoalan utama ketika Pemerintah Daerah memformulasikan perbuatan yang dikenai sanksi pidana ke dalam Peraturan daerah khususnya mengenai pajak dan retribusi daerah.

Bagiamana implementasi teori kebijakan kriminalisasi dalam perumusan ketentuan sanksi pidana dalam peraturan Desa ? mengingat Kondisi faktual dengan adanya Peraturan Daerah yang bermasalah karena belum memperhatikan teori kebijakan kriminalisasi dalam perumusan Peraturan Daerah.

\section{Metode Penelitian}

Tipe penelitian hukum yang dilakukan adalah yuridis normatif (hukum normatif). Metode penelitian hukum normatif adalah suatu prosedur penelitian ilmiah untuk menemukan kebenaran berdasarkan logika

4 Johnny Ibrahim, Teori \& Metode Penelitian Hukum Normatif, Banyumedia Publishing, Malang 2006, h..57 keilmuan hukum dari sisi normatifnya. ${ }^{4}$ Oleh karena itu penelitian hukum ini difokuskan untuk mengkaji penelitian hukum tentang kaidah-kaidah atau normanorma dalam hukum positif

\section{Pembahasan}

\section{A. Kebijakan Kriminalisasi Dalam Peraturan Daerah}

Kebijakan penggunaan sanksi pidana dalam Peraturan Daerah pada hakikatnya dapat dikatakan pula sebagai bagian "politik kriminal" atau "criminal policy". Menurut Marc Ancel, "criminal policy” dapat diberikan pengertian sebagai the rational organization of the control of crime by society.

Dalam hubungan dengan masalah kriminalisasi, Muladi mengingatkan mengenai beberapa ukuran yang secara doktrinal harus diperhatikan sebagai pedoman, yaitu sebagai berikut. ${ }^{5}$

1. Kriminalisasi tidak boleh terkesan menimbulkan "overkriminalisasi" yang masuk kategori the misuse of criminal sanction.

2. Kriminalisasi tidak boleh bersifat ad hoc.

3. Kriminalisasi harus mengandung unsur korban (victimizing) baik aktual maupun potensial.

4. Kriminalisasi harus memperhitungkan analisa biaya dan hasil dan prinsip ultimum remedium.

5 Muladi, Kapita Selekta Hukum Pidana, Badan Penerbit Universitas Diponegoro, Semarang, 1995, h. 256 
5. Kriminalisasi harus menghasilkan peraturan yang enforceable.

6. Kriminalisasi harus mampu memperoleh dukungan publik.

7. Kriminalisasi harus mengandung unsur "subsosialitet" (mengakibatkan bahaya bagi masyarakat, sekalipun kecil sekali).

8. Kriminalisasi harus memperhatikan peringatan bahwa setiap peraturan pidana membatasi kebebasan rakyat dan memberikan kemungkinan kepada aparat penegak hukum untuk mengekang kebebasan itu.

Mengingat pentingnya tahap formulasi dalam fungsionalisasi atau operasionalisasi kebijakan hukum pidana (penal policy), maka kebijakan penggunaan sanksi pidana dalam Peraturan Daerah sebagai bagian dari kebijakan hukum pidana (penal policy) sudah seharusnya memperhatikan ukuran atau kriteria tersebut di atas.

Dasar pertimbangan adanya kebijakan penggunaan sanksi pidana dalam Peraturan Daerah melalui pencantuman ketentuan (ancaman) pidana seharusnya tidak boleh melepaskan dari ukuran atau kriteria dalam kebijakan kriminalisasi. Pembentuk peraturan tidak hanya menetapkan tentang perbuatanperbuatan yang dapat dikenai hukum pidana, tetapi juga menunjuk macammacam sanksi yang dapat diterapkan, begitu pula maksimum ukuran pidana. ${ }^{6}$ Penentuan sanksi apa yang sebaiknya digunakan atau dikenakan kepada si pelanggar mempunyai hubungan yang erat dengan sistem pidana dan pemidanaan. Sistem pidana dan pemidanaan tersebut dapat mencakup ruang lingkup yang cukup luas. Kebijakan kriminalisasi Peraturan Daerah merupakan kompetensi/ kewenangan Pemerintah Daerah untuk membuat Peraturan Daerah, untuk mengetahui kompetensi ini, maka penulis menggunakan teori kompetensi/ kewenangan.

Sanksi pidana dalam Peraturan Daerah masih menekankan pada sanksi pidana pembalasan (teori retributif), yang memandang bahwa pemidanaan merupakan pembalasan atas kesalahan yang telah dilakukan bertujuan memberikan penderitaan kepada pelanggar supaya ia merasakan akibat perbuatannya. Pedoman umum sanksi dalam hukum pidana dapat dibagi menjadi sanksi pidana dan sanksi tindakan. Keduanya bersumber dari ide dasar yang berbeda.

Sanksi pidana bersumber pada ide dasar: "mengapa diadakan pemidanaan", sedangkan sanksi tindakan bertolak dari ide dasar: "untuk apa diadakan pemidanaan itu”. Berdasarkan tujuannya, sanksi pidana dan sanksi tindakan juga bertolak dari ide dasar yang berbeda. Sanksi pidana bertujuan memberi penderitaan istimewa kepada pelanggar supaya merasakan akibat 
perbuatannya, sedangkan sanksi tindakan tujuannya lebih bersifat mendidik. Sesuai dengan perkembangan ilmu pengetahuan hendaknya lebih menitikberatkan pada sanksi tindakan, sanksi itu merupakan sanksi yang tidak membalas, semata-mata ditujukan pada prevensi khusus, terhadap perlindungan masyarakat dari ancaman yang dapat merugikan kepentingan masyarakat itu.

Penetapan sanksi dalam Peraturan Daerah, apapun jenis dan bentuk sanksi harus didasarkan pada kewenangan yang diberikan pada daerah dalam merumuskan Peraturan Daerah pidana dan diorientasikan pada standar tujuan pemidanaan. Setelah tujuan pemidanaan ditetapkan, barulah jenis dan bentuk sanksi apa yang paling tepat bagi pelanggaran Peraturan Daerah itu.

\section{B. Materi Muatan Sanksi dalam Peraturan Desa}

Materi muatan mengenai ketentuan pidana hanya dapat dimuat dalam: ${ }^{7}$

a. Undang-Undang;

b. Peraturan Daerah Provinsi; atau

c. Peraturan Daerah Kabupaten/Kota.

Maria Farida Indrati Soeprapto berpendapat bahwa ketentuan pidana merupakan ketentuan yang tidak mutlak ada dalam peraturan perundang-undangan,

7 Maria Farida Indrati Soeprapto. 2007. Ilmu Perundang-Undangan Proses dan Teknik Pembentukannya. Kanisius: Yogyakarta. h. 99 sehingga perumusan ketentuan pidana tersebut tergantung pada masing-masing peraturan perundang-undangan.

Berdasarkan penjelasan tersebut, meskipun peraturan desa merupakan jenis peraturan perundang-undangan yang diakui keberadaannya dan mempunyai kekuatan hukum mengikat, tetapi peraturan desa tidak dapat memuat sanksi pidana.

Apabila terjadi pelanggaran terhadap pelaksanaan Peraturan Desa yang telah ditetapkan, Badan Permusyawaratan Desa berkewajiban mengingatkan dan menindaklanjuti pelanggaran dimaksud sesuai dengan kewenangan yang dimiliki. Itulah salah satu fungsi pengawasan yang dimiliki oleh Badan Permusyawaratan Desa. Selain Badan Permusyawaratan Desa, masyarakat Desa juga mempunyai hak untuk melakukan pengawasan dan evaluasi secara partisipatif terhadappelaksanaan Peraturan Desa.

\section{Kesimpulan}

Teori pemidanaan dan tujuan pemidanaan dalam konteks penetapan sanksi pidana pada tahap kebijakan legislasi belum dipahami secara utuh sehingga jenis dan bentuk-bentuk sanksi di dalam Peraturan Daerah bukan saja menimbulkan ketidak konsistenan Peraturan Daerah yang satu dengan yang lain, tetapi juga penetapan 
Jurnal Independent Fakultas Hukum

sanksi dirasakan kurang objektif dan rasional. Aspek materi hukum Peraturan Daerah Pidana harus ditumbuhkan acuhan dalil di samping sinkronisasi dengan hukum yang berada diatasnya dengan menggunakan prinsip "lex superiori derogat legi inferiori”, juga harus diperhatikan aspek kesetaraan dengan menggunakan prinsip "lex specialis derogat legi generali";

\section{Daftar Pustaka}

Barda Nawawi Arif, Bunga Rampai Kebijakan Hukum Pidana, PT. Citra Aditya Bakti, Bandung, 1996.

Johnny Ibrahim, Teori \& Metode Penelitian Hukum Normatif, Banyumedia Publishing, Malang 2006.

Maria Farida Indrati Soeprapto. Ilmu Perundang-Undangan Proses dan Teknik Pembentukannya. Kanisius: Yogyakarta. 2007.

Muladi, Kapita Selekta Hukum Pidana, Badan Penerbit Universitas Diponegoro, Semarang, 1995.

Roeslan Saleh, Segi Lain Hukum Pidana, Ghalia Indonesia, Jakarta, 1984.

Teguh Prasetyo, Kebijakan Kriminalisasi Peraturan Daerah Guna Mewujudkan Sinkronisasi Hukum Pidana Lokal dengan Hukum Pidana Kodifikasi, Disertasi, Program Pascasarjana Fakultas Hukum Universitas Islam Indonesia, Yogyakarta ,2006. 